\title{
Glycans of the trabecular meshwork in primary open angle glaucoma
}

\author{
S A Chapman, R E Bonshek, R W Stoddart, E O’Donoghue, K Goodall, D McLeod
}

\begin{abstract}
Aims-Glycan expression was compared in glaucomatous trabecular meshwork (TM) and normal TM in order to determine any differences which may reflect pathological changes underlying primary open angle glaucoma (POAG).

Methods-Resin embedded TM from trabeculectomy specimens from 15 eyes with POAG and from 12 eyes with normal anterior segments were probed with a panel of biotinylated lectins and an avidin-peroxidase revealing system at the light microscope level. Statistical analyses were performed on the comparative staining results.

Results-The lectins ConA and ePHA showed strong staining in all areas of both glaucomatous and normal TM; ePHA staining of Schlemm's canal (SC) from POAG TM was significantly less than that from normal TM (ePHA-SC $p=0 \cdot 04)$. The lectins PSA, LCA, and SNA bound moderately strongly to SC endothelium and weakly to the endothelium of the corneoscleral meshwork (CSM); glaucomatous SC endothelial binding was significantly less than that of normal SC endothelium for PSA and LCA (PSA-SC $p=0.002$, LCA-SC $p=0.002$ ). STA and DSA showed moderately strong binding while WGA, ECA, AHA, and MPA bound weakly throughout the TM; for DSA and MPA this staining was significantly greater in POAG than in normal $T M$ (DSA-SC $p=0.001$, DSA-CSM $p=0.002$, MPA-SC $p=0.01$, MPA-CSM $p=0 \cdot 02)$. Jac stained strongly throughout the $T M$ and showed no significant difference in POAG compared with normal TM (Jac-SC $p=0 \cdot 6$, Jac-CSM p=1). 1PHA, SBA, DBA, CTA, UEA-1 and LTA did not bind to glaucomatous TM or normal TM. There were no age-related changes seen.

Conclusions-The expression of some complex and hybrid, bisected and nonbisected $\mathrm{N}$-linked glycans is significantly diminished in glaucomatous TM compared with normal TM. Some glycans with multiple $N$-acetylglucosamine residues and $O$-linked glycans with terminal and subterminal galactosyl groups are significantly increased in POAG TM. Glycan expression does not change significantly with age in POAG or normal TM.

(Br f Ophthalmol 1996; 80: 435-444)
\end{abstract}

The morphological changes observed in the human trabecular meshwork (TM) and
Schlemm's canal (SC) in primary open angle glaucoma (POAG) are well documented. ${ }^{1-6}$ Despite considerable research, however, the pathogenesis of this condition remains unresolved. ${ }^{7}$ One of the major histological characteristics of TM from eyes with POAG is a lower cellularity compared with normal TM. ${ }^{8-10}$ Other features which are usually associated with cellular degeneration include pigment accumulation and increased basement membrane deposition. ${ }^{11} 12$ It is also well known that such alterations may be seen to a lesser extent as part of the normal aging process. $^{813}$ Because of these observations, trabecular cell dysfunction has been implicated in the pathogenesis of POAG. ${ }^{8} 1113$

The glycans of cell surface glycoproteins are important in determining structural and functional properties such as cellular permeability, ${ }^{14}$ resistance of glycoproteins to degradation, ${ }^{15}$ and surface antigenic characteristics, ${ }^{16}$ so changes or aberrations in cell surface glycoconjugates may reflect pathological changes within the cell. ${ }^{17}{ }^{18}$ Previous investigations of the glycoconjugates of the TM have included a comparative histochemical study ${ }^{19}$ which concluded that there is a greater concentration of sialic acid groups on the abluminal surface of SC endothelium in the TM of glaucomatous tissue compared with normal tissue. The lectins of Canavalia ensiformis (ConA), Triticum vulgaris (WGA), Phaseolus vulgaris erythroagglutinin (ePHA), and Ulex europaeus (UEA-1) have also been used in a comparative lectin binding study of TM from normal and glaucomatous eyes, ${ }^{20}$ but this employed lectin binding to western blots of polyacrylamide gels prepared from TM extracts and so could not localise the lectin binding sites within the tissue.

In a previous report on the glycans of normal human TM, ${ }^{21}$ we used the biotinylated lectins of Sambucus nigra (SNA), Maackia amurensis (MAA), and Limax flavus (LFA) as probes at the ultrastructural level. We demonstrated that sialic acid is present mainly in $\alpha(2,6)$ linkage in the SC endothelium, and in $\alpha(2.3)$ linkage where it is associated with extracellular fibrillar material in the juxtacanalicular tissue (JCT). In the present study, we have selected 20 lectins on the basis of their preferential binding to the main groups of D-pyranose sugars (most commonly occurring in $\mathrm{N}$ - and $\mathrm{O}$-linked glycoproteins) namely, glucose/mannose, galactose/

Abbreviations:

$\alpha$-D-man, $\alpha$-D-mannose; $\alpha$-D-Glc, $\alpha$-D-glucose; GalNAc, $\mathrm{N}$-acetylgalactosamine; fuc, fucose; GlcNAc, $\mathrm{N}$-acetylglucosamine; Neu5Ac, $5 \mathrm{~N}$-acetylneuraminic acid (sialic acid). 
Table 1 Details of the age, presurgical antiglaucomatous medication, and last pretrabulectomy intraocular pressure of patients with primary open angle glaucoma

\begin{tabular}{|c|c|c|}
\hline Age (years) & Medication & $I O P(\mathrm{~mm} \mathrm{Hg})$ \\
\hline $\begin{array}{l}41 \\
50 \\
51 \\
67 \\
68 \\
68 \\
69 \\
70 \\
72 \\
78 \\
78 \\
81 \\
81\end{array}$ & $\begin{array}{l}\text { Pilocarpine 4\%, Eppy } 1 \% \text {, Metipranolol } 0 \cdot 3 \% \\
\text { Pilocarpine, Betoptic 0.5\% } \\
\text { Pilocarpine } 2 \% \text {, Timoptol } 0 \cdot 25 \% \text {, Diamox } \\
\text { Pilocarpine 4\%, Ganda, Diamox } \\
\text { Pilocarpine } 2 \% \text {, Timoptol } 0 \cdot 25 \% \\
\text { Pilocarpine } 2 \% \text {, Timolol, Allopurinol } 300 \mathrm{mg} \\
\text { Pilocarpine } 3 \% \text {, Ganda } 0 \cdot 2 \% \text {, Timoptol } 0 \cdot 25 \% \\
\text { Pilocarpine } 2 \% \text {, Eppy } 5 \% \text {, Glaucine } 0 \cdot 3 \% \\
\text { NA } \\
\text { Pilocarpine } 2 \% \text {, Eppy } 1 \% \text {, Betoptic } 0 \cdot 5 \% \text {, Diamox } \\
\text { NA } \\
\text { NA } \\
\text { Pilocarpine } 2 \% \text {, Timoptol } 0 \cdot 25 \% \text {, Diamox Predsol } \\
\text { Pilocarpine } 4 \% \text {, Timoptol } 0 \cdot 25 \% \text {, Diamox } \\
\text { Diamox, Timoptol } 0 \cdot 25 \%\end{array}$ & $\begin{array}{l}20(28) \\
\mathrm{NA} \\
24(27) \\
15(28) \\
24(24) \\
18(27) \\
27(28) \\
40 \text { (NA) } \\
24 \text { (NA) } \\
\mathrm{NA} \\
\mathrm{NA} \\
16(60) \\
30 \text { (NA) } \\
34(40)\end{array}$ \\
\hline
\end{tabular}

IOP=intraocular pressure before operation. Figure in brackets is the highest recorded IOP. $\mathrm{NA}=$ not available
SC. A description of the trabeculectomy group, with the presurgical antiglaucomatous medication of the subjects, is shown in Table 1 ; none had undergone laser trabeculoplasty. The age range of the subjects providing the 15 trabeculectomy specimens was 41-83 years. The specimens (which were approximately $2 \times 1 \times 1 \mathrm{~mm}$ in size) were immediately fixed in $5 \%(\mathrm{v} / \mathrm{v})$ formaldehyde containing $0 \cdot 1 \%(\mathrm{w} / \mathrm{v})$ cetylpyridinium chloride. Following a 24 hour wash in $0.01 \mathrm{M}$ sodium cacodylate, $\mathrm{pH} 7.4$, containing $3 \mathrm{mM}$ calcium chloride, the tissue blocks were processed into Araldite resin. Briefly, the procedure was as follows: the tissue was dehydrated in graded alcohols $(40 \%, 70 \%$, and $100 \mathrm{v} / \mathrm{v}$ ), immersed in propylene oxide (two changes of 10 minutes), and left overnight in equal parts (v/v) of Araldite epoxy resin (Araldite MY 753, Ciba Geigy, Cambridge) to propylene oxide. Infiltration was continued the next day with a $3 / 1(\mathrm{v} / \mathrm{v})$ mixture of resin to propylene oxide, before finally embedding in undiluted Araldite. Polymerisation was carried out at $60^{\circ} \mathrm{C}$ for 12 hours.

The normal trabecular meshworks were obtained from 12 human eyes (age range 32-84 years) and have been reported previously. ${ }^{22}$ These eyes comprised four specimens obtained at necropsy within 3 hours after death, and eight tissue blocks of whole globes with malignant melanoma arising in the posterior choroid and no other pathology (selected from the archives of the Pathology Department, Manchester Royal Eye Hospital). All eight melanoma eyes had normal intraocular pressure before enucleation.

The eyes from necropsy were fixed in $2.5 \%$ (v/v) glutaraldehyde in $0.01 \mathrm{M}$ sodium cacodylate buffer $\mathrm{pH} 7 \cdot 4$. Part of the iridocorneal angle was then removed and cut into pieces $1 \mathrm{~mm}$ thick which were washed in $0.01 \mathrm{M}$ sodium cacodylate buffer containing $3 \mathrm{mM}$

Table 2 Biotinylated lectins used in this study: those with similar specificities are grouped together

\begin{tabular}{|c|c|c|c|}
\hline Source & Abbrev & Major specificity & Reference \\
\hline \multirow{3}{*}{$\begin{array}{l}\text { Canavalia ensiformis (jack bean) } \\
\text { Pisum sativum (garden pea) } \\
\text { Lens culinaris (lentil) } \\
\text { Phaseolus vulgaris } \\
\text { erythroagglutinin (kidney bean) } \\
\text { Phaseolus vulgaris leucoagglutinin } \\
\text { (kidney bean) }\end{array}$} & ConA & $\begin{array}{l}\alpha \text {-D-man, } \alpha \text {-D-Glc, terminal or } \alpha 1,2 \mathrm{~N} \text {-linked sequences. Bisected or } \\
\text { non-bisected }\end{array}$ & 2627 \\
\hline & $\begin{array}{l}\text { PSA } \\
\text { LCA } \\
\text { ePHA }\end{array}$ & $\begin{array}{l}\alpha-D-m a n \text { in non-bisected bi/tri antennary complex } \mathrm{N} \text { linked sequences } \\
\alpha-\mathrm{D}-\mathrm{man}, \text { similar to but not identical with PSA } \\
\text { Bisected bi/tri antennate complex } N \text { linked sequences }\end{array}$ & $\begin{array}{ll}27 & 28 \\
27 & 29 \\
30 & 31\end{array}$ \\
\hline & 1PHA & Tri/tetra antennate non-bisected complex $\mathrm{N}$ linked sequences & 32 \\
\hline \multicolumn{4}{|l|}{ Glycine max (soybean) } \\
\hline \multirow{3}{*}{$\begin{array}{l}\text { Bandeiraea simplicifolia } \\
\text { (Griffonia) } \\
\text { Erythrina corallodendron (coral } \\
\text { tree) } \\
\text { Erythrina crystagalli (coral tree) }\end{array}$} & DBA & GalNAc $\alpha 1,3$ (Fuc $\alpha 1,2)$ Gal $\beta 1,4$ GlcNAc- & 3536 \\
\hline & BSA-1 $B_{4}$ & Gal $\alpha 1,3 \mathrm{Gal} \beta 1,4 \mathrm{GlcNAc} \beta 1-$ & 37 \\
\hline & CTA & Gal $\beta 1,4 G l c N A c-(m u l t i p l e)$ & 38 \\
\hline \multirow{2}{*}{$\begin{array}{l}\text { Triticum vulgaris (wheat germ) } \\
\text { Solanum tuberosum (potato) } \\
\text { Datura stramonium (Jimson } \\
\text { weed) }\end{array}$} & ECA & Gal $\beta 1,4$ GlcNAc- & 39 \\
\hline & $\begin{array}{l}\text { WGA } \\
\text { STA } \\
\text { DSA }\end{array}$ & $\begin{array}{l}(-4 \mathrm{GlcNAc} \beta 1,4 \mathrm{GlcNAc} \beta 1-)_{\mathrm{n}},(-3 \mathrm{Gal} \beta 1,4 \mathrm{GlcNAc} \beta 1-)_{\mathrm{n}} \\
\text { - } \beta 1,4 \mathrm{GlcNAc} \text { oligomers } \\
\text {-GlcNAc } \beta 1,4 \mathrm{GlcNAc-}\end{array}$ & $\begin{array}{l}2640 \\
27 \\
2741\end{array}$ \\
\hline $\begin{array}{l}\text { Arachis hypogaea (peanut) } \\
\text { Maclura pomifera (Osage } \\
\text { orange) } \\
\text { Artocarpus integrifolia (Jacalin) }\end{array}$ & $\begin{array}{l}\text { AHA } \\
\text { MPA }\end{array}$ & $\begin{array}{l}\text { Gal } \beta 1,3 \text { GalNAc } \alpha 1->\text { Gal } \beta 1,4 \text { Glc NAc } \alpha 1- \\
\text { Gal } \beta 1,3 \text { GalNAc } \alpha 1->\text { GalNAc } 1 \text { 1- }\end{array}$ & $\begin{array}{l}42 \\
43\end{array}$ \\
\hline \multirow{2}{*}{$\begin{array}{l}\text { Ulex europaeus (gorse) } \\
\text { Tetralogonolobus purpureus } \\
\text { (lotus) }\end{array}$} & Jac & Gal $\beta 1,3$ GalNAc-, Gal $\alpha$ 1,6- & 44 \\
\hline & $\begin{array}{l}\text { UEA-1 } \\
\text { LTA }\end{array}$ & $\begin{array}{l}\text { Fuc } \alpha 1,2 \mathrm{Gal} \beta 1,4 \mathrm{GlcNAc}- \\
\alpha-\mathrm{L}-\text { fucosyl terminals }\end{array}$ & $\begin{array}{l}4546 \\
45\end{array}$ \\
\hline \multirow[t]{2}{*}{$\begin{array}{l}\text { Sambucus nigra (elderberry } \\
\text { bark) } \\
\text { Maackia amurensis }\end{array}$} & SNA & Neu5Ac $\alpha 2,6 \mathrm{Gal} / \mathrm{GalNAc}-$ & 47 \\
\hline & MAA & Neu5Ac $\alpha 2,3 \mathrm{Gal} \beta 1,4 \mathrm{Glc} / \mathrm{GlcNAc-}$ & 48 \\
\hline
\end{tabular}


Table 3 Inhibition of lectin binding by specific sugars

\begin{tabular}{lll}
\hline Lectin & Inhibitory sugar & Concentration \\
\hline ConA & $\alpha$ MeMan & $0 \cdot 2 \mathrm{M}$ \\
PSA & $\alpha$ MeMan & $0 \cdot 2 \mathrm{M}$ \\
LCA & $\alpha$ MeMan & $0 \cdot 2 \mathrm{M}$ \\
ePHA & None & \\
1PHA & None & $1 \mathrm{mM}$ \\
SBA & $\alpha$-D-GalNAc & $1 \mathrm{mM}$ \\
DBA & $\alpha$-D-GalNAc & $0 \cdot 2 \mathrm{M}$ \\
BSA1B & $\alpha$-D-Galactose & $0 \cdot 2 \mathrm{M}$ \\
CTA & $\alpha$-D-Galactose & $0 \cdot 2 \mathrm{M}$ \\
ECA & $\alpha$-D-Galactose & $1 \mathrm{mM}$ \\
WGA & (GlcNAc) & $1 \mathrm{mM}$ \\
STA & (GlcNAc) & \\
DSA & (GlcNAc) & \\
AHA & $\alpha-D-G a l a c t o s e$ & $1 \mathrm{mM}$ \\
MPA & $\alpha$-D-Galactose & $1 \mathrm{mM}$ \\
Jac & $\alpha$-D-Galactose & $0 \cdot 2 \mathrm{M}$ \\
UEA-1 & L-fucose & $0 \cdot 2 \mathrm{M}$ \\
LTA & L-fucose & $1 \mathrm{mM}$ \\
SNA & None & $1 \mathrm{mM}$ \\
MAA & None & \\
\hline
\end{tabular}

$\alpha \operatorname{MeMan}=\alpha$-methyl mannopyranoside

$(\mathrm{GlcNAc})_{2}=\mathrm{d}-\mathrm{N}$-acetylchitobiose

calcium chloride. The tissue was then processed as detailed above for the trabeculectomy specimens. To process the melanoma specimens previously embedded in paraffin wax, part of the angle was cut from each block. The tissue was dewaxed in xylene at $60^{\circ} \mathrm{C}$ for 1 hour, passed through alcohols, and rehydrated into sodium cacodylate buffer $\mathrm{pH} \mathbf{7 \cdot 4}$. The tissue was then processed and re-embedded in undiluted Araldite as above.

\section{LECTIN HISTOCHEMISTRY}

A panel of 20 biotinylated lectins (obtained from Sigma, Poole, Dorset, EY Labs [Bradsure Biologicals Ltd, Leics] or Boehringer Mannheim, East Sussex) was used to identify specific carbohydrate sequences

Table 4 Median ranking scores of lectin binding to 15 glaucomatous trabecular meshwork specimens

\begin{tabular}{|c|c|c|c|c|}
\hline \multirow[b]{2}{*}{ Lectin } & \multirow{2}{*}{$\begin{array}{l}\text { Schlemm's canal } \\
\text { endothelium }\end{array}$} & \multirow{2}{*}{$\begin{array}{l}\text { Fuxtacanalicular } \\
\text { tissue }\end{array}$} & \multicolumn{2}{|c|}{$\begin{array}{l}\text { Corneoscleral } \\
\text { meshwork }\end{array}$} \\
\hline & & & $E C$ & $C$ \\
\hline ConA & $3 \cdot 5$ & 3 & 3 & 2 \\
\hline & $3 \cdot 5$ & 3 & 3 & 2 \\
\hline PSA & $\begin{array}{l}2 \\
2\end{array}$ & $\begin{array}{l}2 \\
2\end{array}$ & $\begin{array}{l}2 \\
2\end{array}$ & $2^{1.5}$ \\
\hline LCA & $2 \cdot 5$ & 2 & 2 & 2 \\
\hline ePHA & 3 & 3 & 3 & 2 \\
\hline & 3 & 3 & 3 & 3 \\
\hline BSA-1 $B_{4}$ & $0 \cdot 5$ & 0.5 & 0.5 & 0.5 \\
\hline ECA & $\begin{array}{l}0.5 \\
1.5\end{array}$ & $\begin{array}{l}0 \cdot 5 \\
1\end{array}$ & $\begin{array}{l}0.5 \\
1\end{array}$ & $\begin{array}{l}0 \cdot 5 \\
1\end{array}$ \\
\hline & 2 & $2 \cdot 3$ & 2 & 2 \\
\hline WGA & 2 & 2 & 2 & 1 \\
\hline & $1 \cdot 5$ & 2 & $1 \cdot 5$ & $1 \cdot 5$ \\
\hline STA & 3 & 2 & 2 & 1 \\
\hline DSA & $\begin{array}{l}3 \\
3\end{array}$ & 3 & 2 & 2 \\
\hline ASA & 3 & 3 & 2 & 2 \\
\hline AHA & 0.5 & 0 & 0 & 0 \\
\hline & 0.5 & $0 \cdot 1$ & 0.1 & 0.5 \\
\hline MPA & $1 \cdot 5$ & 1.5 & $1 \cdot 5$ & 1.5 \\
\hline & $1 \cdot 5$ & $1 \cdot 5$ & 1.5 & $1 \cdot 5$ \\
\hline Jac & 4 & 4 & 3 & 3 \\
\hline SNA & $\begin{array}{l}4 \\
3\end{array}$ & $\begin{array}{l}4 \\
3\end{array}$ & $\begin{array}{l}3 \\
2\end{array}$ & $\begin{array}{l}3 \\
2\end{array}$ \\
\hline & 1 & $1 \cdot 5$ & $1 \cdot 5$ & 1 \\
\hline MAA & 1.5 & 1.5 & 1.5 & 1 \\
\hline & $1 \cdot 5$ & 1 & 1 & 1 \\
\hline
\end{tabular}

$\mathrm{EC}=$ endothelial cell, $\mathrm{C}=$ core of trabecular beam; figures in bold=pretreated with neuraminidase.

Staining: $4=$ intense, $3=$ moderately strong; $2=$ medium $1=$ weak, $0=$ none.
Table 5 Median ranking scores of lectin binding to 12 normal trabecular meshwork specimens

\begin{tabular}{|c|c|c|c|c|}
\hline \multirow[b]{2}{*}{ Lectin } & \multirow{2}{*}{$\begin{array}{l}\text { Schlemm's canal } \\
\text { endothelium }\end{array}$} & \multirow{2}{*}{$\begin{array}{l}\text { Fuxtacanalicular } \\
\text { tissue }\end{array}$} & \multicolumn{2}{|c|}{$\begin{array}{l}\text { Corneoscleral } \\
\text { meshwork }\end{array}$} \\
\hline & & & $E C$ & $C$ \\
\hline ConA & $\begin{array}{l}4 \\
3 \cdot 5\end{array}$ & $\begin{array}{l}4 \\
3 \cdot 5\end{array}$ & $\begin{array}{l}3.5 \\
3.5\end{array}$ & $\begin{array}{l}3.5 \\
3.5\end{array}$ \\
\hline PSA & $\begin{array}{l}3 \cdot 5 \\
2\end{array}$ & $\begin{array}{l}2 \\
2\end{array}$ & $\begin{array}{l}2 \\
2\end{array}$ & $2^{1 \cdot 5}$ \\
\hline LCA & $\begin{array}{l}3.5 \\
2.5\end{array}$ & $\begin{array}{l}2.5 \\
2 \cdot 5\end{array}$ & $\frac{1 \cdot 5}{2}$ & $\begin{array}{l}1 \\
2\end{array}$ \\
\hline ePHA & $\begin{array}{l}4.0 \\
3.5\end{array}$ & $\begin{array}{l}3.5 \\
3\end{array}$ & $\begin{array}{l}3.5 \\
3.5\end{array}$ & $\begin{array}{l}2 \\
2 \cdot 5\end{array}$ \\
\hline BSA-1 $B_{4}$ & $\begin{array}{l}0.5 \\
1\end{array}$ & $\begin{array}{l}0.5 \\
1\end{array}$ & $\begin{array}{l}0.5 \\
1\end{array}$ & $\begin{array}{l}0.5 \\
1\end{array}$ \\
\hline ECA & 1 & 1 & 1 & $1 \cdot 5$ \\
\hline WGA & $\begin{array}{l}1.0 \\
1.5\end{array}$ & $\begin{array}{l}1 \\
1\end{array}$ & $\begin{array}{l}1 \cdot 5 \\
1\end{array}$ & $\begin{array}{l}1 \\
1\end{array}$ \\
\hline STA & $\begin{array}{l}3.5 \\
3.5\end{array}$ & $\begin{array}{l}3 \\
3 \cdot 5\end{array}$ & $\begin{array}{l}2.5 \\
3.5\end{array}$ & $\begin{array}{l}2 \\
2 \cdot 5\end{array}$ \\
\hline DSA & $\begin{array}{l}1.5 \\
1.5\end{array}$ & $\begin{array}{l}1.5 \\
1.5\end{array}$ & $\begin{array}{l}1.5 \\
1.5\end{array}$ & $\begin{array}{l}1 \\
1\end{array}$ \\
\hline AHA & $\begin{array}{l}0 \\
1 \cdot 5\end{array}$ & $\begin{array}{l}0 \\
1.5\end{array}$ & $\begin{array}{l}0.5 \\
1.5\end{array}$ & $\begin{array}{l}0.5 \\
1\end{array}$ \\
\hline MPA & $\begin{array}{l}0.5 \\
2\end{array}$ & $\begin{array}{l}0.5 \\
2\end{array}$ & $\begin{array}{l}0.5 \\
2\end{array}$ & $\begin{array}{l}0.5 \\
1\end{array}$ \\
\hline Jac & $\begin{array}{l}4 \\
4\end{array}$ & $\begin{array}{l}4 \\
4\end{array}$ & $\begin{array}{l}3 \\
4\end{array}$ & $\begin{array}{l}2 \cdot 5 \\
2 \cdot 5\end{array}$ \\
\hline SNA & $\begin{array}{l}3.5 \\
1.5\end{array}$ & $\begin{array}{l}3.5 \\
1.5\end{array}$ & $\begin{array}{l}2 \\
1 \cdot 5\end{array}$ & $\begin{array}{l}2 \\
1 \cdot 5\end{array}$ \\
\hline MAA & 1.5 & $1 \cdot 5$ & 1 & $\begin{array}{l}1 \\
1 \cdot 5\end{array}$ \\
\hline
\end{tabular}

$\mathrm{EC}=$ endothelial cell, $\mathrm{C}=$ core of trabecular beam; figures in bold $=$ pretreated with neuraminidase.

Staining: $4=$ intense, $3=$ moderately strong; $2=$ medium $1=$ weak, $0=$ none.

(Table 2). The method (detailed in a previous study ${ }^{22}$ ) was carried out as follows. The resin embedded sections ( $1 \mu \mathrm{m}$ thick) were put onto multispot slides (C A Hendley, Essex), precoated with aminoalkyl silane ${ }^{23}$ (Sigma) and dried at $37^{\circ} \mathrm{C}$ overnight. Epoxy resin was removed from each section by etching for 15 minutes with $50 \%(\mathrm{w} / \mathrm{v})$ saturated sodium ethoxide solution in absolute ethanol. The sections were rehydrated using $100 \%, 70 \%$, and $40 \%(v / v)$ alcohol solutions and finally distilled water. Endogenous peroxidase activity was blocked with $10 \%(\mathrm{v} / \mathrm{v})$ hydrogen peroxide (diluted from $30 \% \mathrm{v} / \mathrm{v}$ ) for 8 minutes. Sections were then trypsinised with $0 \cdot 1 \%(w / v)$ crude trypsin (type II, Sigma) in $0.05 \mathrm{M}$ TRIS-buffered saline (TBS) $\mathrm{pH} 7 \cdot 6$, containing $0 \cdot 1 \%(\mathrm{w} / \mathrm{v})$ calcium chloride, for 5 minutes at $37^{\circ} \mathrm{C}$. Biotinylated lectin (Table 2) was then applied at a concentration of $10 \mu \mathrm{g} / \mathrm{ml}$ in $0.05 \mathrm{M}$ TBS, $\mathrm{pH} 7 \cdot 6$, containing $1 \mathrm{mM}$ calcium chloride, and the sections were incubated at $37^{\circ} \mathrm{C}$ for 60 minutes. The sections were given three 5 minute washes in TBS with $1 \mathrm{mM}$ calcium chloride before being incubated in avidin peroxidase (Sigma) at a concentration of $5 \mu \mathrm{g} / \mathrm{ml}$ in $0.125 \mathrm{M}$ TBS for 60 minutes. ${ }^{24}$ After three 5 minute washes in TBS, the lectin binding sites were visualised with a $0.05 \%(w / v)$ solution of diaminobenzidine hydrochloride (DAB) in TBS containing cobaltous ions $(\mathrm{ml} / 100 \mathrm{ml}$ of $1 \%(\mathrm{w} / \mathrm{v})$ cobaltous chloride solution). ${ }^{25}$ Sections were placed in this solution and, after 4 minutes, $0.015 \%(\mathrm{v} / \mathrm{v})$ hydrogen peroxide was added and staining continued for a further 3 minutes. The sections were washed in running tap water for 2 minutes, dried, and mounted in XAM (Gurr, Speke, Liverpool). 

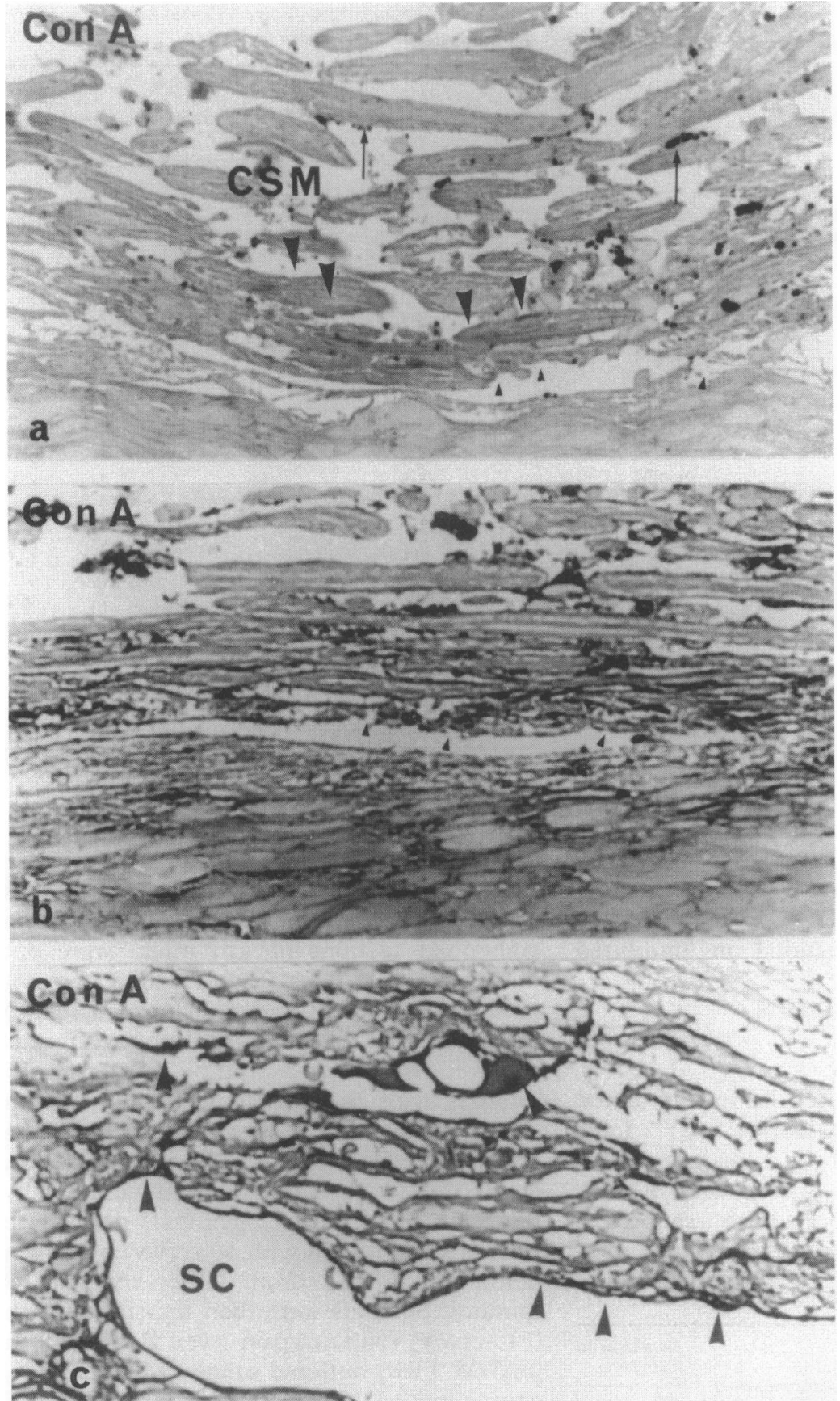

Figure 1 ConA staining of trabecular meshwork (TM) from primary open angle glaucoma (POAG) (a,b) and normal (c) TM. (a) Moderately strong staining of trabecular cells (arge arrowheads) and cores of beams of POAG corneoscleral meshwork (CSM). Schlemm's canal (SC) endothelium is present with some apparent disruption (arrowheads). Melanin is visible as dense, particulate deposits (arrows) and can be clearly distinguished from diaminobenzidine hydrochloride deposit which is more diffuse

(magnification $\times 536$ ). (b) ConA binding to a different glaucomatous TM. Staining of trabecular cells in the CSM and juxtacanalicular tissue (fCT) and both inner and outer SC endothelium as well as adjacent sclera is stronger than in (a) (staining intensity is graded 4 compared with 3 in (a)). Discontinuity with possibly some endothelial deficit is visible in SC endothelium (arrowheads) (magnification $\times 536$ ). (c) SC endothelium and trabecular cells of the normal CSM stain very strongly (large arrowheads) (magnification $\times 536)$.
Table 6 Group 1 versus group 2 Mann-Whitney U test

\begin{tabular}{|c|c|c|c|}
\hline Lectin & Median 1 & Median 2 & $p$ Value \\
\hline ConA-SC & $3 \cdot 5$ & $4 \cdot 0$ & $0 \cdot 18$ \\
\hline ConA-CSM & 3.0 & 3.0 & 0.38 \\
\hline PSA-SC & $2 \cdot 0$ & 3.5 & $0.002^{\star}$ \\
\hline PSA-CSM & $2 \cdot 0$ & $2 \cdot 0$ & $0 \cdot 87$ \\
\hline LCA-SC & $2 \cdot 5$ & $3 \cdot 5$ & $0 \cdot 002^{\star}$ \\
\hline LCA-CSM & $2 \cdot 0$ & $2 \cdot 0$ & 0.61 \\
\hline ePHA-SC & $3 \cdot 0$ & 3.5 & $0 \cdot 04^{\star}$ \\
\hline ePHA-CSM & $3 \cdot 0$ & $3 \cdot 5$ & $0 \cdot 25$ \\
\hline ECA-SC & $1 \cdot 0$ & $1 \cdot 0$ & 0.33 \\
\hline ECA-CSM & $1 \cdot 0$ & 1.5 & $0 \cdot 14$ \\
\hline WGA-SC & $2 \cdot 0$ & 1.5 & $0 \cdot 27$ \\
\hline WGA-CSM & $2 \cdot 0$ & $2 \cdot 0$ & $0 \cdot 14$ \\
\hline 1PHA-SC & $1 \cdot 0$ & 0 & $0 \cdot 28$ \\
\hline 1PHA-CSM & 1.0 & 0 & 0.09 \\
\hline STA-SC & $3 \cdot 0$ & 3.5 & $0 \cdot 28$ \\
\hline STA-CSM & $2 \cdot 0$ & $2 \cdot 5$ & 0.71 \\
\hline DSA-SC & $3 \cdot 0$ & 1.5 & $0.001^{\star}$ \\
\hline DSA-CSM & $3 \cdot 0$ & 1.5 & $0.002^{\star}$ \\
\hline AHA-SC & 0 & 0 & 0.31 \\
\hline AHA-CSM & 0 & 0 & 0.96 \\
\hline MPA-SC & 1.5 & $1 \cdot 0$ & $0.01^{\star}$ \\
\hline MPA-CSM & 1.5 & 1.0 & $0.02^{\star}$ \\
\hline Jac-SC & 4 & 4 & 0.6 \\
\hline Jac-CSM & 3 & 3 & $1 \cdot 0$ \\
\hline SNA-SC & $3 \cdot 0$ & 3.5 & 0.45 \\
\hline SNA-CSM & 2 & 2 & 0.67 \\
\hline MAA-SC & 1.5 & $1 \cdot 0$ & $0 \cdot 04^{\star}$ \\
\hline MAA-CSM & 1.5 & $1 \cdot 0$ & $0.01 *$ \\
\hline
\end{tabular}

${ }^{\star} \mathrm{p}$ Value $<0.05$ is significant.

NEURAMINIDASE DIGESTION

After etching, blocking of endogenous peroxidase and trypsinisation, some of the sections were incubated in 0.1 units $/ \mathrm{ml}$ neuraminidase (from Clostridium perfringens, type VI, Sigma) in $0.2 \mathrm{M}$ sodium acetate buffer, $\mathrm{pH} 5 \cdot 5$, containing $1 \%(\mathrm{w} / \mathrm{v})$ calcium chloride for 1 hour at $37^{\circ} \mathrm{C}$. After washing, sections were treated with the selected biotinylated lectins $(10 \mu \mathrm{g} / \mathrm{ml})$ and avidin peroxidase $(5 \mu \mathrm{g} / \mathrm{ml})$ and visualised with $\mathrm{DAB} /$ cobalt as described above.

\section{STATISTICAL ANALYSIS}

Four groups were analysed: group 1 (glaucomatous TM), group 2 (normal TM), group 3 (neuraminidase treated glaucomatous TM), and group 4 (neuraminidase treated normal TM). For each group the staining results with each lectin for SC endothelium (lectin-SC) and for the endothelium of corneoscleral meshwork (lectin-CSM) were included in the analysis. The results for the JCT were excluded as they were very similar to the results for the CSM endothelium. Lectin staining was evaluated by a ranked procedure for a representative section of each specimen, based on a scale of $0-4$ where $0=$ no staining, $1=$ weak staining, $2=$ moderate staining, $3=$ moderately strong staining, and $4=$ intense staining. Intermediate results were classified as $1 \cdot 5,2 \cdot 5$, and $3 \cdot 5$. Staining with some lectins was very weak or possibly zero. For these, only ranks 0 and 1 were used. Grading of staining intensity was evaluated by consensus between two of the authors (SAC and REB). It was not possible to perform the evaluations masked because the source of the tissue was apparent from its morphology.

Groups 1 and 2 and groups 3 and 4 were compared by the Mann-Whitney $U$ test for independent samples where the ranking was spread over the range $0-4$. A cross tabulation method for the $\chi^{2}$ test was used when staining was rated 0 or 1 . each experimental run. The specificity of lectin binding was confirmed by inhibitory sugars at appropriate concentrations where possible (Table 3). The effect of neuraminidase (see below) was taken as confirmation of lectin specificity for sialyl residues. 

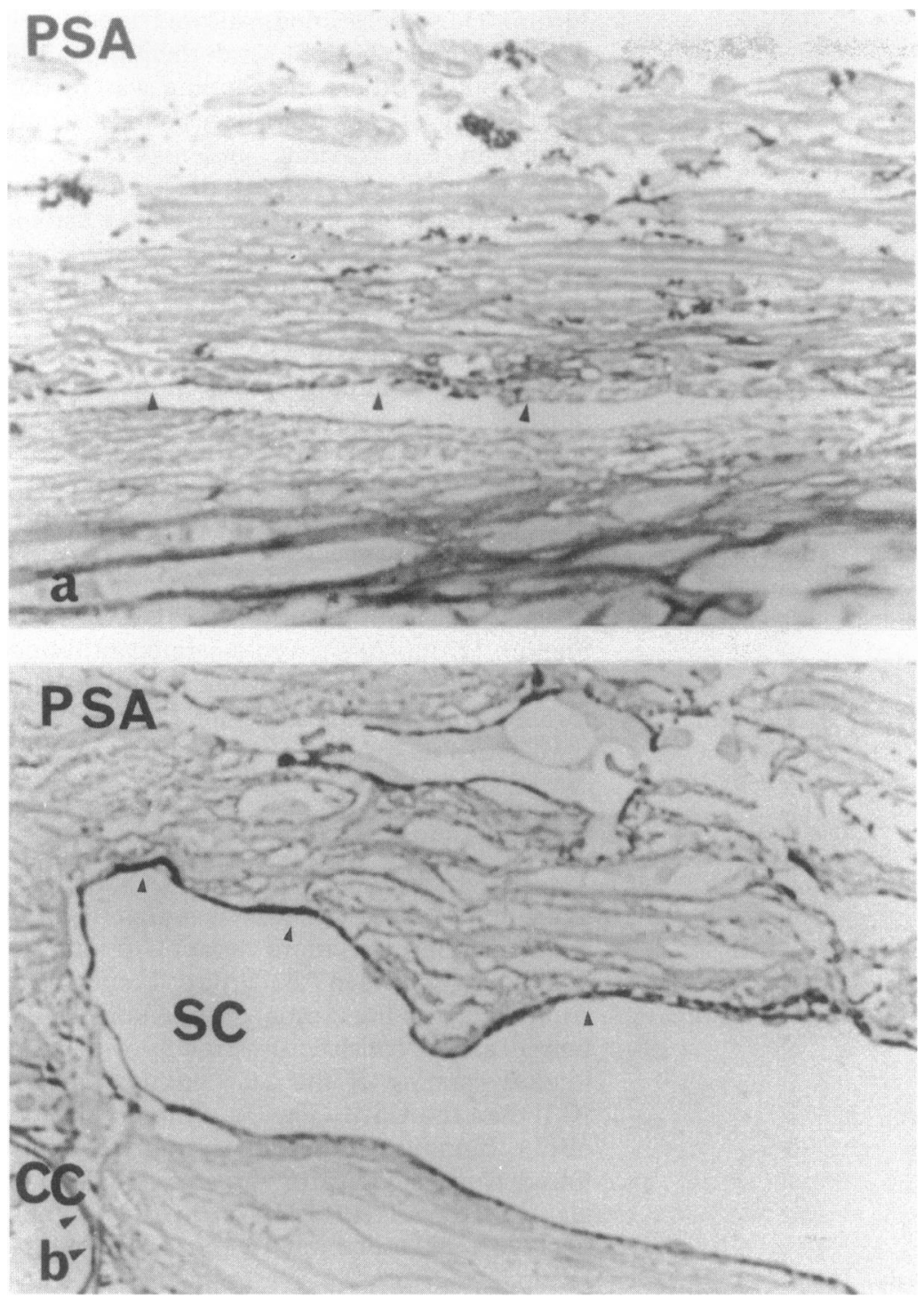

Figure 2 PSA staining of trabecular meshwork (TM) from primary open angle glaucoma (a) and normal (b) TM. (a) Variable and intermittent staining of Schlemm's canal (SC) endothelium can be seen (small arrowheads) with weaker staining of the TM

(magnification $\times 536)$. (b) Continuous strong staining of collector channel (CC) and SC endothelium is evident (arrowheads) (magnification $\times 536$ ).

Groups 1 and 3 and groups 2 and 4 were compared by the Wilcoxon matched pairs signed ranks test. The McNemara test for related variables, with two values only, was used for analysis where lectin staining was ranked 0 or 1 .

To test for correlation between patient age and intensity of lectin staining, Spearman correlation coefficients were determined for groups 1 and 2.

All analyses were performed using the SPSS (SPSS Inc) software package.

\section{Results}

\section{LECTIN HISTOCHEMISTRY}

The specimens of TM from the POAG patients (group 1) showed a broadly consistent pattern of lectin staining with no obvious differences corresponding to the different earlier drug regimes of the subjects. There were variations in the morphology of SC and TM in the POAG specimens and in five cases SC appeared to be compressed or blocked so that the canal was not patent and the canal
Table 7 Group 1 versus group 3 Wilcoxon matched pairs

\begin{tabular}{llll}
\hline Lectin & Median 1 & Median 3 & $p$ Value \\
\hline ConA-SC & 3.5 & 3.5 & 0.75 \\
ConA-CSM & 3.0 & 3.25 & 0.80 \\
PSA-SC & 2.0 & 3.0 & 0.30 \\
PSA-CSM & 2.0 & 2.0 & 0.47 \\
LCA-SC & 2.5 & 3.0 & 0.90 \\
LCA-CSM & 2.0 & 2.0 & 0.17 \\
ePHA-SC & 3.0 & 3.0 & 0.18 \\
ePHA-CSM & 3.0 & 3.0 & 0.14 \\
ECA-SC & 1.5 & 2.25 & $0.03^{\star}$ \\
ECA-CSM & 1.0 & 1.75 & $0.01^{\star}$ \\
WGA-SC & 1.75 & 1.5 & 0.91 \\
WGA-CSM & 1.5 & 1.25 & 0.39 \\
BSA-SC & 0.5 & 0.5 & 0.39 \\
BSA-CSM & 0.5 & 0.5 & 0.39 \\
STA-SC & 3.0 & 3.0 & $0.04^{\star}$ \\
STA-CSM & 2.5 & 3.0 & 0.23 \\
DSA-SC & 3.0 & 3.0 & 0.23 \\
DSA-CSM & 2.75 & 3.0 & 0.31 \\
AHA-SC & 0.5 & 0.5 & 0.75 \\
AHA-CSM & 0.5 & 0.5 & 0.75 \\
MPA-SC & 1.5 & 1.5 & 0.50 \\
MPA-CSM & 1.5 & 1.5 & 0.68 \\
Jac-SC & 4.0 & 4.0 & 0.36 \\
Jac-CSM & 3.5 & 3.75 & 0.40 \\
SNA-SC & 3.0 & 1.0 & $0.01^{\star}$ \\
SNA-CSM & 2.5 & 1.25 & $0.01^{\star}$ \\
MAA-SC & 1.5 & 1.5 & 0.90 \\
MAA-CSM & 1.5 & 1.5 & 0.90 \\
\hline
\end{tabular}

$\star_{p}$ Value $<0.05$ is significant.

endothelium was less clearly defined. In three cases the canal endothelium was incomplete or was apparently absent.

Table 4 gives the median scores of lectin staining of the glaucomatous TM and SC and Table 5 gives the median results of lectin binding to the TM from the normal eyes (discussed in more detail in a previous report ${ }^{22}$ ). The re-embedding of the eight normal eyes from wax into Araldite and the different fixative used did not result in any inconsistencies in the staining pattern compared with that of tissue which was embedded straight into Araldite after glutaraldehyde fixation. The determination of Spearman correlation coefficients showed that there was no significant correlation between lectin staining and age in either group 1 or group 2 with any of the lectins despite the wide age ranges (41-83 years and $32-84$ years respectively).

Table 8 Group 2 versus group 4 Wilcoxon matched pairs

\begin{tabular}{|c|c|c|c|}
\hline Lectin & Median 2 & Median 4 & p Value \\
\hline $\begin{array}{l}\text { ConA-SC } \\
\text { ConA-CSM } \\
\text { PSA-SC } \\
\text { PSA-CSM } \\
\text { LCA-SC } \\
\text { LCA-CSM } \\
\text { ePHA-SC } \\
\text { EPHA-CSM } \\
\text { ECA-SC } \\
\text { ECA-CSM } \\
\text { WGA-SC } \\
\text { WGA-CSM } \\
\text { STA-SC } \\
\text { STA-CSM } \\
\text { DSA-SC } \\
\text { DSA-CSM } \\
\text { AHA-SC } \\
\text { AHA-CSM } \\
\text { MPA-SC } \\
\text { MPA-CSM } \\
\text { Jac-SC } \\
\text { Jac-CSM } \\
\text { SNA-SC } \\
\text { SNA-CSM } \\
\text { MAA-SC } \\
\text { MAA-CSM }\end{array}$ & $\begin{array}{l}4 \cdot 0 \\
3 \cdot 25 \\
3 \cdot 5 \\
2 \cdot 0 \\
3 \cdot 75 \\
2 \cdot 25 \\
4 \cdot 0 \\
3 \cdot 5 \\
1.0 \\
1.5 \\
1 \cdot 0 \\
1 \cdot 0 \\
3 \cdot 0 \\
2 \cdot 0 \\
1.5 \\
1.5 \\
0 \\
0.5 \\
1.0 \\
1.0 \\
4.0 \\
3 \cdot 0 \\
3 \cdot 5 \\
3.0 \\
1.0 \\
1.25\end{array}$ & $\begin{array}{l}3.5 \\
3.5 \\
2.0 \\
1.5 \\
2.25 \\
2.25 \\
3.5 \\
3.5 \\
1.5 \\
1.5 \\
1.5 \\
1.0 \\
3.0 \\
3.0 \\
1.5 \\
1.5 \\
1.5 \\
1.5 \\
1.5 \\
1.5 \\
4.0 \\
4.0 \\
2.0 \\
1.5 \\
1.0 \\
1.25\end{array}$ & 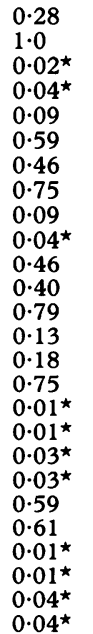 \\
\hline
\end{tabular}

${ }^{\star} \mathrm{p}$ Value $<0.05$ is significant. 

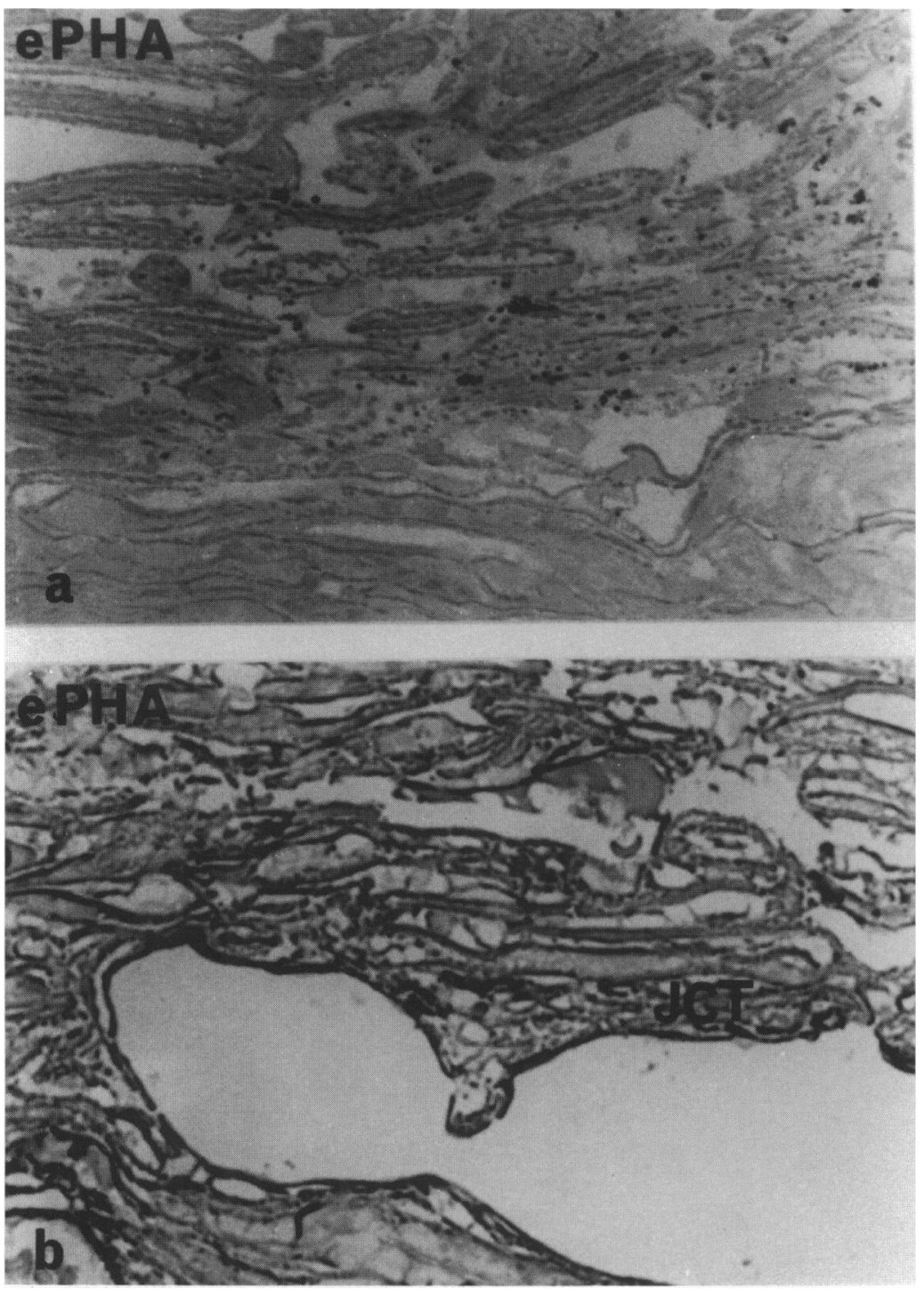

Figure 3 ePHA staining of trabecular meshwork (TM) from primary open angle glaucoma (a) and normal (b) TM. (a) Moderately weak binding to TM and Schlemm's canal (SC) endothelium (magnification $\times 618$ ). (b) Strong staining of SC endothelium and slightly weaker staining of juxtacanalicular tissue (FCT) and trabecular cells of corneoscleral meshwork (magnification $\times 618$ ).

\section{ConA binding}

ConA bound moderately strongly to SC endothelium, JCT, and CSM (except the cores of beams) of the glaucomatous tissue (group 1), with some variation between cases (Figs 1a and b). Staining of SC endothelium was variable and in some cases there were discontinuities in the pattern of surface staining (although the endothelium was still intact). In normal TM (group 2), ConA staining was strong throughout, particularly in the SC endothelium where staining was continuous (Fig 1c). Statistically there was no difference in staining intensity between glaucomatous (group 1) and normal (group 2) TM (ConA-SC, $p=0 \cdot 18$, ConACSM, $p=0.38$ Table 6 ), but there was greater variation of staining within group 2 .

\section{PSA and LCA binding}

The binding of PSA and LCA to the JCT and CSM was less intense than that of ConA in both glaucomatous (group 1) and normal tissue (group 2) and there was variation between the two groups in the staining of SC endothelium. In the glaucomatous tissue (group 1), some sections showed moderately weak binding to both SC endothelium and the CSM, but in others the staining was moderately strong. There were occasional discontinuities in the staining, either because the endothelium was present but the lectin binding was irregularly weak, or because of deficits in the endothelium (Fig 2a). The SC endothelium of normal tissue (group 2), on the other hand, showed continuous and moderately strong binding of PSA (Fig 2b) and LCA. This stronger staining of SC endothelium in normal tissues was shown to be statistically significant (PSA-SC, $p=0.002$, LCA-SC, $p=0.002$ Table 6 ). PSA staining of glaucomatous TM (group 1) was not affected by pretreatment with neuraminidase (PSA-SC, $\mathrm{p}=0.30$, PSA-CSM, $\mathrm{p}=0.47$ Table 7) whereas normal SC endothelium and CSM endothelium (group 2) showed a significant reduction in PSA staining following treatment with this enzyme (PSA-SC, $p=0.02$, PSA-CSM, $\mathrm{p}=0.04$ Table 8 ).

\section{ePHA and $1 P H A$ binding}

The pattern and intensity of ePHA staining of glaucomatous TM was similar to that of ConA and again there was more variation in intensity of staining between the group 1 specimens compared with the normal group. Normal TM bound ePHA consistently strongly with more intense staining of the SC endothelium and JCT than the CSM (Figs 3a, 3b) and group 2 ePHA binding to the SC endothelium was found to be significantly greater than that in glaucomatous TM (ePHA-SC, $p=0.04$ Table 6) 1PHA did not bind to the TM of either group.

\section{$W G A, S T A$, and $D S A$ binding}

The staining patterns of WGA and STA (which have overlapping binding requirements) showed differences in affinity and localisation from each other but not between groups 1 and 2 . In both groups WGA bound weakly to all parts of the TM whereas STA stained with greater intensity on the SC endothelium than the JCT and CSM. DSA staining, on the other hand, was statistically greater in glaucomatous (group 1) than in normal TM (DSA-SC, $\mathrm{p}=0.001$, DSA-CSM, $\mathrm{p}=0.002$ Table 6).

\section{ECA binding}

ECA bound weakly throughout the TM in both groups. Pretreatment with neuraminidase significantly increased the staining with ECA in both series (Figs 4a, 4b) (ECA-SC, $p=0.03$, ECA-CSM, $p=0.01$ Table 7; ECA-CSM, $\mathrm{p}=0.04$ Table 8)

\section{SNA and $M A A$ binding}

The sialic acid specific lectins SNA and MAA showed different binding patterns from each other. SNA bound strongly to the inner and outer walls of the SC, the JCT, and to a much 

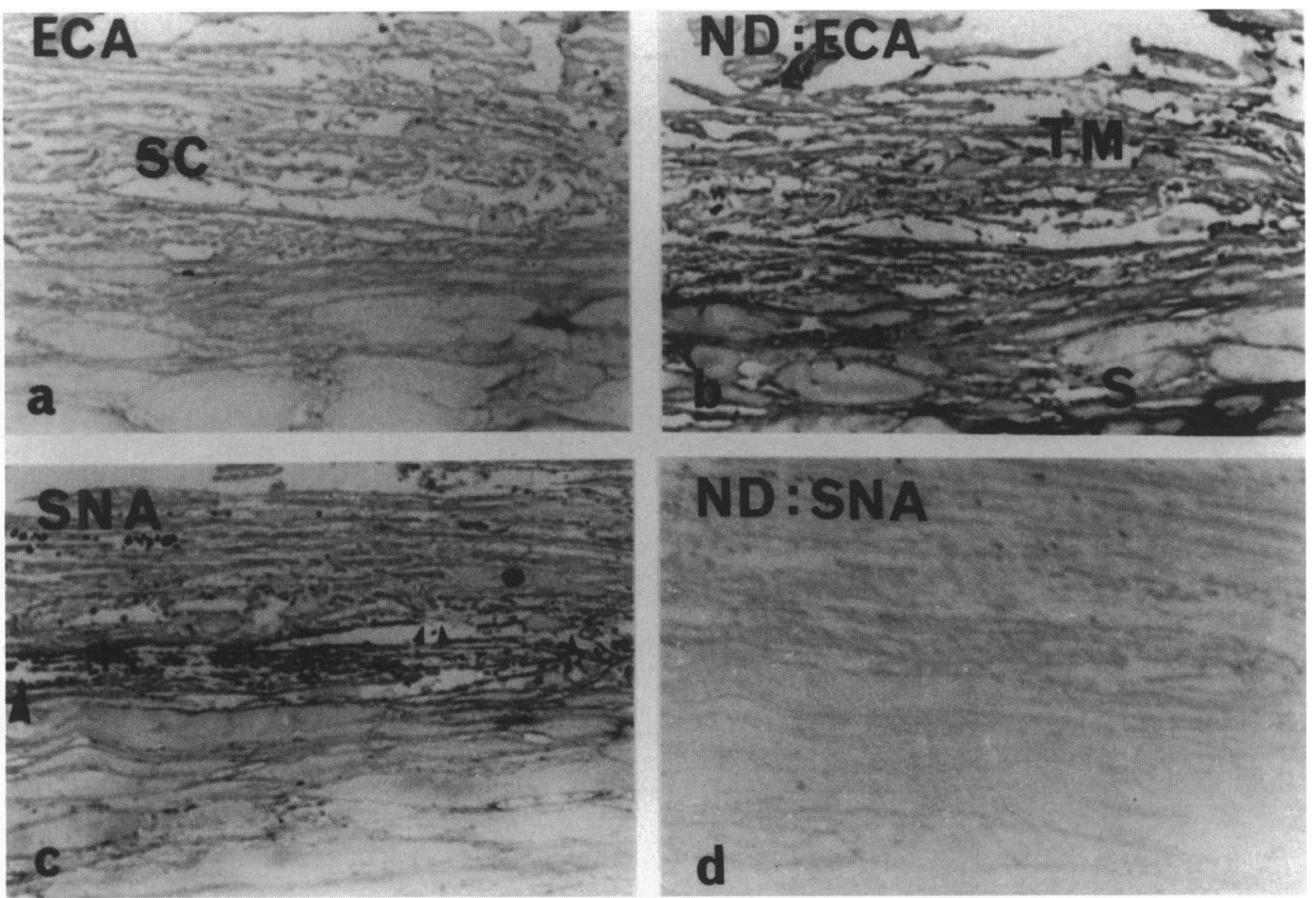

Figure 4 The effect of pretreatment with neuraminidase on ECA staining $(a, b)$ and SNA staining $(c, d)$ of primary open angle glaucoma trabecular meshwork (TM). (a) Despite damage to the tissue, there is weak staining throughout the TM. Narrowed lumen of Schlemm's canal (SC) is visible (magnification $\times 588$ ). (b) Pretreatment with neuraminidase increases ECA staining throughout the section which includes TM and sclera (S) (magnification $\times 588$ ). (c) Strong staining of SC endothelium with some discontinuity where a cell body can be seen (arrowheads). Other deficits in the $S C$ endothelium are more likely to be a result of trauma (large arrowheads) (magnification $\times 588$ ). (d) Pretreatment with neuraminidase reduces SNA staining (magnification $\times 588$ ).


Figure 5 fac staining of trabecular meshwork (TM) from primary open angle glaucoma (a) and normal (b) TM. (a) Schlemm's canal (SC) endothelium shows quite strong but intermittent staining (small arrowheads). Trabecular cells show variable staining with weaker binding to the cores of beams (large arrowheads) (magnification $\times 522$ ).

(b) Strong but intermittent staining of SC endothelium (small arrowheads) and continuous staining of cells of juxtacanalicular tissue and corneoscleral meshwork (large arrowheads) (magnification $\times 522)$. lesser extent, the trabecular cells of the CSM in both groups. There were some discontinuities in the trabeculectomy tissue and the staining of the SC appeared slightly weaker than in normal meshwork but this was not statistically significant. Staining with SNA in both groups (Figs 4c, 4d) was reduced significantly, though not completely, after pretreatment with neuraminidase (glaucomatous TM SNA-SC, $\mathrm{p}=0.01$, SNA-CSM, $\mathrm{p}=0.01$ Table 7; normal TM SNA-SC, $p=0.01$, SNA-CSM, $p=0.01$ Table 8). MAA, on the other hand, bound weakly throughout the TM of both groups of specimens. Binding was significantly increased in normal TM following treatment with neuraminidase (MAA-SC, $\mathrm{p}=0.04, \mathrm{MAA}-\mathrm{CSM}$, $p=0.04$ Table 8 ) but was unaffected in glaucomatous TM.

\section{fac, $M P A, A H A$, and $B S A-1 B_{4}$ binding}

Jac bound strongly throughout the outflow pathway in both groups and with greatest intensity in the JCT and SC endothelium where, in both the glaucomatous (group 1) and normal tissue (group 2), staining was sometimes irregular (Figs 5a, 5b). MPA bound weakly in both groups but statistically more avidly in Group 1 (MPA-SC, $p=0.01$, MPA-CSM, $p=0.02$ Table 6). However, although MPA and AHA have a similar specificity, there was negligible binding with AHA. Pretreatment with neuraminidase did not affect MPA binding to glaucomatous TM but there was a significant increase in binding to normal TM (MPA-SC, $p=0.03$, MPA-CSM, $p=0.03$ Table 8). AHA binding to normal TM also significantly increased after neuraminidase 
Table 9 Group 3 versus group 4 Mann-Whitney U test

\begin{tabular}{llll}
\hline Lectin & Median 3 & Median 4 & $p$ Value \\
\hline ConA-SC & 3.5 & 3.5 & 0.93 \\
ConA-CSM & 3.25 & 3.5 & 0.54 \\
PSA-SC & 3.0 & 2.0 & 0.07 \\
SA-CSM & 2.0 & 1.5 & 0.05 \\
LCA-SC & 3.0 & 2.25 & 0.90 \\
LCA-CSM & 2.5 & 2.25 & 0.96 \\
ePHA-SC & 3.0 & 3.5 & 0.46 \\
ePHA-CSM & 3.0 & 3.0 & 0.52 \\
ECA-SC & 2.25 & 1.5 & 0.06 \\
ECA-CSM & 1.75 & 1.5 & 0.35 \\
WGA-SC & 1.5 & 1.5 & 0.33 \\
WGA-CSM & 1.25 & 1.0 & 0.73 \\
BSA-SC & 0.5 & 1.0 & $0.01^{\star}$ \\
BSA-CSM & 0.5 & 1.0 & $0.02^{\star}$ \\
STA-SC & 3.0 & 3.0 & 0.82 \\
STA-CSM & 3.0 & 3.0 & 0.72 \\
1PHA-SC & 0.25 & 0 & 0.63 \\
1PHA-CSM & 0.25 & 0 & 0.63 \\
AHA-SC & 0.5 & 1.5 & $0.01^{\star}$ \\
AHA-CSM & 0.5 & 1.5 & $0.01^{\star}$ \\
MPA-SC & 1.5 & 1.5 & 0.79 \\
MPA-CSM & 1.5 & 1.5 & 0.82 \\
Jac-SC & 4.0 & 4.0 & 0.64 \\
Jac-CSM & 3.75 & 4.0 & 0.93 \\
SNA-SC & 1.0 & 2.0 & 0.09 \\
SNA-CSM & 1.25 & 1.5 & 0.5 \\
MAA-SC & 1.5 & 1.25 & 0.61 \\
MAA-CSM & 1.5 & 1.25 & 0.61 \\
* & & & \\
\hline * & & &
\end{tabular}

${ }^{\star} \mathrm{p}$ Value $<0.05$ is significant.

(AHA-SC, p=0.01, AHA-CSM, p=0.01 Table 8) while binding to glaucomatous TM was unaffected. The resultant AHA binding to normal TM, following this enzyme digestion, was significantly greater than for glaucomatous TM (AHA-SC, $p=0.01$, AHA-CSM, $p=0.01$

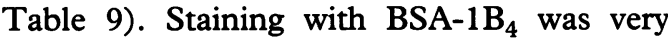
weak throughout the meshwork in both groups following pretreatment with neuraminidase.

Other lectins

SBA, DBA, CTA, UEA-1, and LTA showed negligible staining in all parts of the $T M$ in both groups. The McNemar test for related groups where results have only two values showed no significant test results for lectins SBA, DBA, CTA, UEA-1, and LTA.

\section{Discussion}

Trabeculectomy tissue is one of the few sources of material readily available for observing the pathological effects of POAG and has been used for morphological ${ }^{549}$ and quantitative studies of meshwork cellularity ${ }^{8}$ and collagen content. ${ }^{50}$ Limitations of trabeculectomy specimens include the small size of the tissue blocks and the potential for distortion of the specimen during the operative procedure. These considerations were taken into account in evaluating this comparative lectin histochemical study of glaucomatous and normal TM and only cases where there was an adequate amount of TM and SC were selected. In some of the trabeculectomy specimens the SC endothelium could not be distinguished clearly because the canal was blocked and, occasionally, the canal endothelium appeared to be missing. This feature of POAG has been reported in earlier studies of trabeculectomy tissue. ${ }^{49} 51$

The moderately strong binding of ConA and ePHA to SC endothelium and JCT in both groups indicates that high mannose $N$-linked glycans (both complex and intermediate) are expressed by the TM of both glaucomatous and normal tissue. The specificities of ConA and ePHA also show that these glycans may be of the bisected or non-bisected subsets and are probably biantennate. More highly branched non-bisected glycans, such as tri/tetra antennate, are not present as there is no reaction with 1PHA. The diminished binding of ePHA to glaucomatous SC endothelium compared with normal TM suggests a reduction in the expression of bisected glycans in the SC endothelium. PSA and LCA also show reduced binding to the SC endothelium of the glaucomatous TM compared with normal tissue which suggests a reduction in some $N$-linked glycans in this area.

A preliminary report of lectin binding to human TM, using SDS/polyacrylamide gel electrophoresis and lectin binding to western blots, ${ }^{20}$. concluded that ConA, 1PHA, and UEA-1 bound more strongly to normal TM than that from POAG subjects. Our findings with respect to ConA show that there is a greater variation in binding in glaucomatous eyes compared with normals but there was no statistically significant difference in median ranking for intensity of staining and hence glycan expression. We found negligible or no binding with both 1PHA and UEA-1. UEA-1 binds to L-fucose, a relatively hydrophobic residue, and the discrepancy (compared with the previous report ${ }^{20}$ ) may reflect the presence of glycolipid. This glycoconjugate is not affected by the biochemical method which uses unfixed, unprocessed tissue but is removed during processing for lectin histochemistry. However, a lectin histochemical study of cultured TM cells (from cynomolgus monkey and bovine eyes) also found no visible staining with UEA-1 $1^{52}$ but positive staining with ConA, AHA, WGA, and PHA (erythroagglutinin and leucoagglutinin combined). The electrophoretic separation of TM components would have used much larger quantities of material than were analysed here, possibly rendering low levels of glycan associated with a particular glycoprotein detectable on lectin blotting.

The binding of STA to both trabeculectomy and normal tissue suggests that trabecular cells express $-\beta 1,4 \mathrm{GlcNAc}$ oligomers, or glycan residues in the form of repeated $N$-acetyllactosamine groups (-Galß1,4GlcNAc-). WGA, DSA, and STA possess similar, but not identical, specificities and the variation in binding between the lectins, in both groups, suggests that different glycans may be involved, particularly as DSA shows more intense staining with glaucomatous than normal TM. DSA has a similar specificity to STA but a greater affinity for multiple $N$-acetylglucosamine groups and can bind to $O$-linked glycans. The weak staining with ECA, which was increased by neuraminidase pretreatment, indicates the presence of subterminal $N$-acetyllactosamine groups with some terminal sialylation. This particular grouping, with $\alpha(2,6)$ linked sialic acid, is known to occur in fibronectin ${ }^{53}$ which has been shown to be present on SC endothelium in aged human eyes ${ }^{54}$ and in the 
subendothelial region of the trabecular beams in normal and trabeculectomy tissue. ${ }^{55}$

Glycans which are $O$-linked to serine or threonine of the protein chain are also present throughout the TM of trabeculectomy and normal tissue as shown by the strong binding of Jac (specific for $\mathrm{Gal} \beta(1,3) \mathrm{GalNAc}$ - and Gal $\alpha(1,6)$ ). MPA (which has similar but not identical specificities) shows statistically stronger staining in glaucomatous TM compared with normal TM. This lesser intensity of staining in normal TM may result from masking by sialic acid groups as neuraminidase pretreatment causes increased MPA binding, whereas there is no statistical difference following desialylation of glaucomatous TM. A biochemical study of trabecular cell surface glycoconjugates in the cynomolgus monkey eye concluded that all accessible terminal galactose/acetyl galactosamine groups were sialylated. ${ }^{56}$

The trabeculectomy specimens used in this . study were from subjects where various combinations of drugs including pilocarpine, Timoptol (timolol), Ganda (guanethidine monosulphate), and Diamox (acetazolamide) prescribed over varying periods of time, had failed to normalise the intraocular pressure. The effect of medication on the morphology and biochemistry of the TM is an important question to be addressed as it is not known what, if any, influence drug therapy might have on the expression of glycan residues present in the TM. The number of patients in this study is insufficient to draw any conclusions about the effect of medication, but a previous comparative study of trabeculectomy specimens for treated and untreated subjects with POAG concluded, following qualitative and quantitative analysis, that medication produces no visible effect on SC and JCT morphology. ${ }^{3}$

We have demonstrated that, from the overall similarity in their lectin binding patterns, there are no major differences in the types of glycans expressed in glaucomatous and normal TM. However, differences were observed in the intensity of staining of certain lectins, suggesting alterations in concentration of some of the glycans, which could reflect either an alteration in glycoprotein levels or glycan content. Thus high mannose, intermediate and complex, non-bisected and bisected $N$-linked glycans (which are not highly branched, but probably biantennary) are expressed in glaucomatous TM, particularly on SC endothelium, to a lesser degree than in normal tissue. Glycans showing an increased expression in glaucomatous TM compared with normal TM are (a) $O$-linked glycans with terminal and subterminal galactose, with concomitantly less sialylation, and/or (b) groups with multiple $N$-acetylglucosamine residues which may be $\mathrm{N}$ - or $\mathrm{O}$-linked to the polypeptide backbone.

It has been suggested that the pathology of POAG is very similar to exaggerated aging changes in normal TM. ${ }^{57}$ However, we found no correlation between age and glycan expression in either normal or glaucomatous TM. We conclude that the observed changes in glycan expression are relevant to the pathogenesis of POAG. Identification of the glycoproteins to which these glycans are linked should provide some insight into the pathological processes which constitute POAG.

The authors wish to thank Valerie Hillier and Tripti Halder, Computational Group, Faculty of Medicine, University of Manchester for advice on the statistical methods and assistance with the data analysis.

Funding was provided by grants from the North West Funding was provided by grants from the North West
Regional Health Authority, the Guide Dogs for the Blind Regional Health Authority, the Guide Dogs for the Blind
Association and Manchester Royal Eye Hospital Research Association and

1 Nesterov AP, Batmanov YE. Trabecular wall of Schlemm's canal in the early stage of primary open angle glaucoma. Am f Ophthalmol 1974; 78: 639-47.

2 Rohen JW, Futa R, Lütjen-Drecoll E. The fine structure of the cribriform meshwork in normal and glaucomatous eyes as seen in tangential section. Invest Ophthalmol Vis $\mathrm{Sci}$ 1981; 21: 574-85.

3 Rohen JW, Lütjen-Drecoll E, Flügel C, Meyer M, Grierson I. Ultrastructure of the trabecular meshwork in untreated cases of primary open-angle glaucoma (POAG). Exp Eye Res 1993; 56: 683-92.

4 Fine BS, Yanoff M, Stone RA. A clinicopathologic study of four cases of primary open angle glaucoma compared to normal eyes. Am $\mathcal{f}$ Ophthalmol 1981; 91: 88-105.

5 Rodrigues MM, Spaeth GL, Sivalingam E, Weinreb S. Histopathology of 150 trabeculectomy specimens in glaucoma. Trans Ophthalmol Soc UK 1976; 96: 245-53.

6 Tripathi RC. Aqueous outflow pathway in normal and glaucomatous eyes. Br $\mathcal{f}$ Ophthalmol 1972; 56: 157-74.

7 Grierson I. Alterations in the outflow system in chronic simple glaucoma. In: McAllister JA, Wilson RP, eds. Glaucoma. London: Butterworths, 1986; 1-29.

8 Alvarado J, Murphy C, Juster R. Trabecular meshwork cellularity in primary open-angle glaucoma and nonglaucomatous normals. Ophthalmology 1984; 91: 564-79.

9 Alvarado JA, Murphy CG, Juster RA, Polansky JR. Studies on the pathogenesis of primary open-angle glaucoma: regional analyses of trabecular meshwork cellularity and dense collagen. In: Ticho U, David R, eds. Recent advances in glaucoma. New York: Elsevier Science, 1984: 3-8.

10 Grierson I, McMenamin PG, Lee WR. The effects of age and antiglaucoma drugs on the meshwork cell population. Res Clin Forums 1982; 4: 69-92.

11 Alvarado JA, Murphy CG. Outflow obstruction in pigmentary and primary open angle glaucoma. Arch Ophthalmol 1992; 110: 1769-78.

12 Shirato S, Murphy CG, Bloom E, Franse-Carman L Maglio MT, Polansky JR, et al. Kinetics of phagocytosis in trabecular meshwork cells. Invest Ophthalmol Vis Sci 1989; trabecular mes $2499-511$.

13 Grierson I, Howes R. Age-related depletion of the cell population in the human trabecular meshwork. Eye 1987 1: 204-10.

14 Quinton PM, Philpott CW. A role for anionic sites in epithelial architecture. $\mathcal{f}$ Cell Biol 1973; 56: 787-96.

15 Corfield AP, Schauer R. In: Schauer R, ed. Sialic acids. metabolism and function. Cell Biology Monograph, vol 10 New York: Springer Verlag, 1982: 195-261.

16 Duk M, Sticher U, Brossmer R, Lisowska E. The differences in significance of $\alpha 2,3 \mathrm{Gal}$-linked and $\alpha 2,6 \mathrm{GalNAc}$ linked sialic acid residues in blood group $M$ - and $\mathrm{N}$-related epitopes recognized by various monoclonal N-related epitopes recognized by various
antibodies. Glycobiology 1994; 4: 175-81.

17 Damjanov I. Biology of disease - lectin cytochemistry and histochemistry. Lab Invest 1987; 57: 5-20.

18 Spicer SS, Schulte BA. Diversity of cell glycoconjugates shown histochemically: a perspective. $\mathcal{f}$ Histochem Cytochem 1992; 40: 1-38.

19 Tripathi RC, Tripathi BJ, Spaeth GL. Localization of sialic acid moieties in the endothelial lining of Schlemm's canal in normal and glaucomatous eyes. Exp Eye Res 1987; 44: 293-306.

20 Tripathi BJ, Marcus CH, Millard CB, Gulcher J, Stefansson K. Monoclonal antibodies and lectins as probes for investigation of the cell biology of human trabecular meshwork: a preliminary report. Ophthalmic Res 1989; 21: 27-32.

21 Chapman SA, Bonshek RE, Stoddart RW, Mackenzie KR McLeod D. Localisation of $\alpha(2,3)$ and $\alpha(2,6)$ linked terminal sialic acid groups in human trabecular meshwork. Br $\mathcal{F}$ Ophthalmol 1994; 78: 632-7.

22 Chapman SA, Bonshek RE, Stoddart RW, Jones CJP, Mackenzie KR, O'Donoghue E, McLeod D. Glycoconjugates of the human trabecular meshwork: a Glycoconjugates of the human trabecular meshwork: a
lectin histochemical study. Histochem $\mathcal{f}$ 1995; 27: 869-81.

23 Maddox PH, Jenkins D. 3-aminopropyltriethoxysilane (APES): a new advance in section adhesion. $\mathcal{f}$ Clin Pathol 1987; 40: $1256-7$.

24 Jones CJP, Stoddart RW. A post-embedding avidin-biotin peroxidase system to demonstrate the light and electron microscopic localization of lectin binding sites in rat kidney tubules. Histochem $\mathcal{F}$ 1986; 18: 371-9.

$25 \mathrm{Hsu}$ SU-M, Soban E. Color modification of diaminobenzidine (DAB) precipitation by metallic ions and its application for double immunohistochemistry. $\mathcal{f}$ Histochem Cytochem 1982; 30: 1079-82.

26 Goldstein IJ, Hayes CE. The lectins: carbohydrate binding proteins of plants and animals. Adv Carbohydr Chem Biochem 1978; 35: 127-340. 
27 Debray H, Decout D, Strecker G, Spik D, Montreuil J Specificity of twelve lectins towards oligosaccharides and glycopeptides related to N-glycosylproteins. Eur f Biochem 1981; 117: 41-55.

28 Trowbridge IS. Isolation and chemical characteristics of a mitogenic lectin from Pisum sativum. F Biol Chem 1974; 249: 6004-12.

29 Kornfeld K, Reitmann ML, Kornfeld R. The carbohydratebinding specificity of pea and lentil lectins. Fucose is an important determinant. F Biol Chem 1981; 256: 6633-40.

30 Cummings RD, Kornfeld S. Characterisation of the structural determinants required for the high affinity interaction of asparagine-linked oligosaccharides with interaction of asparagine-linked oligosaccharides with erythroagglutinating lectins. $\mathcal{f}$ Biol Chem 1982; 257: $11230-4$.

31 Yamashita K, Hitoi A, Kobata A. Structural determinants of Phaseolus vulgaris erythroagglutinating lectin for oligosaccharides. F Biol Chem 1983; 258: 14753-5.

32 Hammarström S, Hammarström ML, Sunblad G, Arnarp J, Lönngren J. Mitogenic leukoagglutinin from Phaseolus vulgaris binds to pentasaccharide unit in $\mathbf{N}$-acetylvulgaris binds to pentasaccharide unit in N-acetyllactosamine-type glycop

33 Pereira MEA, Kabat EA. Immunochemical studies on the specificity of soybean agglutinin. Carbohydr Res 1974; 37: 89-102.

34 Bhattacharyya L, Haraldsson M, Brewer CF. Precipitation of galactose-specific lectins by complex-type oligosaccharides and glycopeptides: studies with lectins from Ricinus communis (Agglutinin I), Erythrina indica, Erythrina arborescens, Abrus precatorius (Agglutinin), and Glycine max (Soybean). Biochemistry 1988; 27: 1034-41.

35 Etzler ME, Kabat EA. Purification and characterisation of a lectin (plant hemagglutinin) with blood group A specificity from Dolichos bifiorus. Biochemistry 1970; 9: 869-77.

36 Torres BV, McCrumb DK, Smith DF. Glycolipid-lectin interactions: reactivity of lectins from Helix pomatia, Wisteria floribunda and Dolichos biflorus with glycolipids containing N-acetylgalactosamine. Arch Biochem Biophys 1988; 262: $1-11$.

37 Wood C, Kabat EA, Murphy LA, Goldstein IJ. Immunochemical studies of the combining sites of the two isolectins, A4 and B4, isolated from Bandeiraea simplicifolia. Arch Biochem Biophys 1979; 198: 1-11.

38 Bhattacharyya LB, Haraldsson M, Sharon N, Lis H, Brewer F. Binding and precipitating activities of Erythrina lectins with complex type carbohydrates and synthetic cluster glycosides. A comparative study of the lectins from $\mathrm{E}$ corallodendron, E cristagalli, E flabelliformis, and E indica. Glycoconjugate $\mathcal{F} 1989 ; 6$ : 141-50.

39 De Boeck H, Loontiens FG, Lis H, Sharon H. Binding of simple carbohydrates and some $\mathrm{N}$-acetyllactosaminecontaining oligosaccharides to Erythrina cristagalli agglutinin as followed with a fluorescent indicator ligand. Arch Biochem Biophys 1984; 234: 297-304.

40 Gallagher JT, Morris A, Dexter TM. Identification of two binding sites for wheat germ agglutinin on polylactosaminetype oligosaccharides. Biochem $\mathcal{F}$ 1985; 231: 115-22.
41 Yamashita K, Totani K, Ohkura T, Takasaki S, Goldstein IJ, Kobata A. Carbohydrate binding properties of Ij, Kobata A. Carbohydrate binding properties of complex-type oligosaccharides on immobilized D

42 Lotan R, Sharon N. Peanut Arachis hypogaea agglutinin. Meth Enzymol 1978; 50: 361-7.

43 Sarkar M, Wu AM, Kabat EA. Immunochemical studies on the carbohydrate specificity of Maclura pomifera lectin. Arch Biochem Biophys 1981; 209: 204-18.

44 Ahmed H, Chatterjee BP. Further characterization and immunochemical studies on the carbohydrate specificity of jackfruit Artocarpus integrifolia lectin. $\mathcal{F}$ Biol Chem 1989; 264: 9365-72.

45 Pereira MEA, Kisailus EC, Gruezo F, Kabat EA. Immunochemical studies on the combining site of the blood group H-specific lectin from Ulex europaeus. Arch Biochem Biophys 1978; 185: 108-15.

46 Petryniak J, Goldstein IJ. Immunochemical studies on the interaction between synthetic glycoconjugates and $\alpha-\mathrm{L}-$ fucosyl binding lectins. Biochemistry 1986; 25: 2829-38.

47 Shibuya N, Goldstein IJ, Broekaert WF, Nsimba-Lubaki M, Peeters B, Peumans WJ. The elderberry (Sambucus nigra) bark lectin recognises the Neu5Ac $\alpha(2-$ 6) Gal/GalNAc sequence. $\mathcal{F}$ Biol Chem 1987; 262: 1596-601.

48 Knibbs RN, Goldstein IJ, Ratcliffe RM, Shibuya N. Characterization of the carbohydrate binding specificity of the leukoagglutinating lectin from Maackia amurensis. f Biol Chem 1991; 266: 83-8.

49 Lee WR, Grierson I. Relationships between intraocular pressure and the morphology of the outflow apparatus. Trans Ophthalmol Soc UK 1974; 94: 430-48.

50 Finkelstein I, Trope GE, Basu PK, Hasany SM, Hunter WS. Quantitative analysis of collagen content and amino acids in trabecular meshwork. Br $\mathcal{f}$ Ophthalmol 1990; 74: 280-2.

51 Alvarado JA, Murphy CG. Outflow obstruction in pigmentary and primary open angle glaucoma. Arch Ophthalmol 1992; 110: 1769-78.

52 Kurosawa A, Elner VM, Yue BYJT, Elvart JL, Tso MOM. Cultured trabecular-meshwork cells: immunohistochemical and lectin-binding characteristics. Exp Eye Res 1987; 45: 239-51.

53 Takasaki S, Yamashita K, Suzuki K, Kobata A. Structural studies of the sugar chains of cold-insoluble globulin isolated from human plasma. $f$ Biochem 1980; 88: isolated $1587-94$.

54 Floyd BB, Cleveland PH, Worthen DM. Fibronectin in human trabecular drainage channels. Invest Ophthalmol Vis Sci 1985; 26: 797-804.

55 Rodrigues MM, Katz SI, Foidart J, Spaeth GL. Collagen, Factor VIII antigen, and immunoglobulins in the human aqueous drainage channels. Ophthalmology 1980; 87: $337-45$.

56 Kress BC, Weinreb RN, Pinney E, Miller AL. Surface glycoconjugates of cynomolgus monkey trabecular cells. Exp Eye Res 1991; 53: 703-7.

57 Grierson I. What is open-angle glaucoma? Eye 1987; 1: 15-28. 